\title{
A Perspective on Perspectives
}

\author{
Jeffrey C. Isaac
}

The most important thing any scholarly journal can do is to publish scholarly research and writing that is both excellent and intellectually engaging. Since it hit the ground running in 2002, Perspectives on Politics has been committed to the highest standards of scholarly publication. At the same time, from its inception Perspectives has been a journal with a difference, seeking to combine scholarly excellence with relevance and readability, and to feature a wide range of formats for and perspectives on the serious study of politics. For the past ten years Perspectives has thus served as an important public sphere for political science in general and especially for the American Political Science Association.

I am extremely proud to serve as only the third editor in the history of this journal, and to introduce this special tenth anniversary issue to our readers. In editing this issue, my staff and I, with the input of our Editorial Board, have sought to produce an issue that showcases the range of formats in which we political scientists can and do produce interesting writing - from research articles and reflective essays to review essays, book-centered symposia and critical dialogues, and conventional book reviews, which through their serious and critical commentary represent public recognition of the centrality of books to political science scholarship. We have also sought with this special issue to highlight the extent to which excellent political science can also be political science that is interesting and relevant, and that addresses broad themes of public consequence.

Post-Katrina New Orleans seemed like an obvious theme around which to organize this issue, because New Orleans is the site of this year's APSA Meeting, which occasions our tenth anniversary celebration; because the New Orleans siting has itself been the source of some significant and productive controversy within our discipline; and because

I would like to thank the following colleagues for their helpful comments on this introductory essay: Michael Brintnall, Mala Htun, Mary Katzenstein, Peter Katzenstein, Robert Keohane, Rogers Smith, Dara Strolovitch, Sid Tarrow, and especially my staff, all named on the masthead as well as in this Introduction.
"New Orleans" broadly encapsulates some very important themes in the study of politics, from power and inequality to urban crisis to post-disaster reconstruction and development to the complex intersections of race, class, gender, and sexuality. This special issue contains terrific pieces that explore these issues, and its diverse combination of pieces and perspectives demonstrates our capacity as political science scholars and as intellectuals to constructively speak to and with each other across conventional subfield and methodological divides within our profession.

In a moment I will introduce these contributions, drawing some general connections and highlighting common themes, as editor introductions typically do. But on the occasion of this tenth anniversary of our journal, I would like first to comment more generally on why Perspectives on Politics - a journal whose excellence preceded my tenure as editor and will continue long after the end of this tenure-is so important to political science.

\section{Perspectives on Politics: A Political Science Public Sphere}

Perspectives is an essential part of a broader process of rethinking that has taken place in American political science over the past two decades or so, mirroring similar processes that have unfolded in other social science disciplines. To even describe the current state of a discipline, much less to analyze its recent history, is to enter an interpretive minefield, a minefield that is all the more hazardous if one is invested with any kind of special influence or official "authority" — which the editorship of this journal surely confers. American political science, like most academic disciplines, is a complex and pluralistic discipline that has always been characterized by serious discussion and sometimes passionate disagreement about its purposes, methods, and goals. At the same time, I think it is fair to say that in recent years the discipline has become increasingly attentive to its historically evolved identity, to its relationships with other disciplines and to the American university system at large, and to its public conditions and consequences. Some of this attentiveness was no doubt linked to the highly publicized "Perestroika" movement within the discipline, which gave voice to long-standing concerns and sought to promote greater methodological 
pluralism and greater transparency and openness in disciplinary institutions.

Perspectives on Politics was created in response to this broad intellectual ferment (See Jennifer Hochschild's careful "Inventing Perspectives on Politics," in Kristen Monroe, ed., Perestroika! The Raucous Rebellion in Political Science" [2005]). One impulse behind the journal's founding was the felt need for the discipline to have a broader public profile, and a venue that, in the words of founding editor Jennifer Hochschild, "reaches across and outside our discipline and seeks to draw all of its members, and others, into a conversation about politics, policy, power, and the study thereof." As Robert Putnam noted in his 2002 APSA Presidential Address, "The Public Role of Political Science," this impulse was hardly new in the discipline, which has experienced continual cycles of argumentation pitting "scientific rigor" against breadth of approach and "relevance," and has progressed through the unfolding of this productive tension. As Putnam wrote: "In all the social sciences, waves of scientism and activism have succeeded one another in a dialectic process. Moreover, this is a matter of more/less, not either/or; and ours is a marvelously diverse profession, so even in the high seasons of activism, large numbers of political scientists have been working steadily at what our colleagues in the physical sciences call 'bench science.' Conversely, even at the highest tides of scientism, plenty of our colleagues have made important contributions to public life. Nevertheless, a more historically situated analysis than I can provide here would, I imagine, show that we are nearing the end of a period in which activism has been de-emphasized and even de-legitimized by our professional norms." Putnam's address powerfully makes the case for a political science that is sophisticated, systematic, and rigorous and also has "a greater public presence" and significance.

If one impulse behind the creation of this journal was a felt need for the profession to address matters of broad public consequence, another was the sense that political science had become hyper-specialized and balkanized, consisting of subgroups of scholars who spoke to one another in increasingly private languages, to the detriment of both collegiality and real intellectual progress. This was clearly the impulse behind Sven Steinmo's 1998 internet campaign to "Take Back the APSR," which resulted in his 1999 election to the APSA Council, and his appointment to the Task Force organized by 2000 APSA President Robert Keohane, which laid some of the groundwork for the eventual creation of Perspectives. But this sense goes back much further. Gabriel Almond articulated a similar concern in his widely-cited 1988 cri de coeur, "Separate Tables: Schools and Sects in Political Science," which bemoaned the fact that increasing numbers of young political scientists were vacating the broad "cafeteria of the center" in favor of the exotic specialties on offer at the "separate tables." Almond wrote as a former leader of the "behav- ioral revolution" now reflecting on a revolution betrayed, a self-described former "Young Turk" who had come to feel that his own broad theoretical background and wideranging interests had marked him as a "dinosaur" in a discipline enamored of "virtuoso mathematical and statistical displays" and other forms of esoteric expression.

Almond's rhetorical appeal to a "vital center" that was in danger of extinction indeed harkened back to the early days of behavioralism, and to its interest in what Ira Katznelson has labeled "political studies enlightenment." It was none other than Almond's colleague David Easton who wrote, in a 1951 Journal of Politics article entitled "The Decline of Political Theory," that: "Under these circumstances, our value framework becomes of crucial significance for what is generally viewed as empirical research. It influences the kind of problem we select for research and the way in which we interpret results. It helps to determine whether the factual problems involved in trying to pursue a set of social policies in political life will be investigated by the social scientist. For unless the latter is constantly aware that he himself does make value decisions, and that his research is inevitably immersed in an ethical perspective, he is apt to forget that social science lives in order to meet human needs. By shying away from his own role as a value builder, as well as analyzer, the research worker is less apt to identify the crucial problems of human life in society that require examination. In part, this search for an amoral science and its correlative hostility to a creative redefinition of values accounts for the feeling today that social science lives isolated in an ivory tower."

The parallels between the intellectual situation Easton described in 1951 and the post-behavioral pathologies bemoaned by Almond in 1988 are striking. The fact that the critical descriptions were offered by leaders of the discipline's move toward a more "scientific" profile who are regarded as heroes of the political science "mainstream" is telling. It underscores the extent to which this journal's mission is grounded on our discipline's foundational commitments.

Perspectives on Politics was created to foster the kind of scholarly reflexivity and broad mindedness that Easton extolled, and that then-APSR editor Lee Siegelman endorsed in 2002, when he called for a greater "intellectual diversity [that] endows political science with vibrancy, energy, and openness to new and often challenging perspectives." It also reflected the thinking behind the APSA Task Force on Graduate Education created in 2002 by then-President Theda Skocpol, which underscored the advantages of social scientific specialization, but also highlighted the pressing need for political scientists to "communicate clearly to each other and to broader publics" why and how their inquiries promote "improved understandings of substantively important features of human life."

Perspectives, in short, represented something new that in fact was also something of a throwback to a time, not 
that long ago, when political scientists across the discipline, regardless of subfield, methodological orientation, or political perspective, could talk meaningfully to each other about their work and could open the pages of their discipline's "flagship journal" and read everything or almost everything - not just article abstracts or introductions and conclusions, but entire articles — with genuine understanding and interest. At the dawn of the twentyfirst century American political science, only a century old in institutional terms, seemed to have outgrown such a possibility. The size of the profession seemed to warrant creating a second journal to feature reviews and essays, thus making more space in the APSR for more specialized research. More importantly, the increased sophistication and specialization of political science research, and the heightened sense of epistemic expertise that attended the "maturation" of political science as a profession and as a scientific discipline, made it increasingly difficult for political scientists to do and to share their "best" research in ways that were broadly intelligible even to their own disciplinary colleagues. The discipline, in short, seemed to have lost its core-a common, public language of concepts and concerns capable of facilitating serious critical engagement, mutual understanding, and intellectual learning across the field as a whole, and thus indirectly beyond the field.

Into this breach stepped a new and exciting journal-a second "flagship journal" of the American Political Science Association-this journal, Perspectives on Politics.

\section{Perspectives on Politics: A Moment of Gratitude}

We academic scholars often take for granted the institutional conditions of the work that we do, whether these conditions be academic departments and programs, professional associations, or the means of scholarly publication. Scholarly journals are very complicated and demanding institutions, requiring the cultivation of high degrees of trust and intellectual commitment among large numbers of colleagues and requiring the cooperation of editors, editorial staff, disciplinary associations, publishers, copy editors, printers, and, in recent years, managers of electronic systems. Most of all, they require the interest of readers, reviewers, and published contributors. Even the very best and most established journals must work hard to sustain all of these commitments. To start a new journal, from scratch, represents a truly Promethean undertaking.

And so it is with enormous gratitude and pleasure that I would like to recognize, and to thank, Jennifer Hochschild, this journal's founding editor. Jennifer put together a terrific team: Managing Editor Thomas Kozachek; Associate Editors Lisa Burrell, Henry Brady, William Galston, Atul Kohli, Paula McClain, Kevin McKenna, and Jack Snyder, some of our profession's most respected members; Editorial Assistants Michael Fortner, Brian Glenn,
Melissa Kayongo, Daniel Kenney, Jason Lakin, Eric Lomazoff, Anna Nelson, and Meg Rithmire; Book Review Editors Susan Bickford and Greg McAvoy, and their Editorial Assistants Brett M. Altman, Dustin Ells Howes, Elizabeth Markovits, Carisa R. Showden, and M. Erin N. Taylor. These people, and others unnamed, worked together to create the journal you now are reading and to establish it as a venue for broad and accessible political science research and writing.

I would also like to thank, and recognize, Jennifer's successor and my predecessor, James Johnson. As the journal's second editor-in-chief, James faced three exceptionally difficult challenges: to institutionalize the excitement, and routinize the "charisma," that attended the journal's creation; to give further definition to a journal that was in some ways all things to all people, to its benefit but also to its disadvantage; and to bring the journal fully into the twenty-first century, by introducing the new Editorial Manager system of online article submission, review, and correspondence. James worked diligently to meet these challenges, in the face of some very trying situations. He did so with the support of an excellent team that included Managing Editor Linda F. Lindenfelser; Associate Editors Michael Desch, Martha Finnemore, Clark Gibson, Ruth W. Grant, and Walter R. Mebane, Jr.; and Editorial Assistants Deniz Aksoy, Matthew Jacobsmeier, and Matthew Platt. James' Book Review Editor was yours truly.

I am happy not only to thank Jennifer and James (and their teams), but also to include specially commissioned "Reflections" essays by both of them in this issue. Jennifer and James were both highly respected scholars before taking over the journal and both of them have resumed their scholarly research agendas. It is terrific to be able to include them, and their exciting and relevant work, in this special issue.

I have worked on this journal for seven of its first ten years, having served as Book Review Editor for four years before assuming editorship of the entire operation three years ago. I have actually written quite a bit-in the editor introductions I've been writing for the past seven years, and in other venues, including annual reports and editorial statements-about the things we have tried to do with the journal, and the ways that we have built on the innovations that we first initiated with the Book Review, where we institutionalized new formats-Critical Dialogues and Book Symposia - and initiated the practice of regular editorial introductions of books and book reviews. For now, I would like simply, but crucially, to thank those whose work and collegiality have made it possible for me to do what I have done over the past seven years. I would like to thank my excellent, engaged, and dedicated Editorial Board. Because the board is large and growing, I will not list all of its members here, but I will call attention to the masthead, where their names appear. I would also like to thank Michael Brintnall and Polly Karpowicz of APSA; Mark 
Zadrozny, Susan Soule, Jonathan Geffner, and Michael Marvin of Cambridge; Gerri Quashnie of Beljan; the support team at Aries; our copy-editors, Linda Lindenfelser, Maurice Meilleur, Phyllis Berk, Melanie Loewhing, and Amy Perlow; Russ Hanson, Larry Singell, Jean Robinson, Michael McRobbie, and their administrative predecessors and colleagues at Indiana University, who have generously supported the journal for seven years going on ten years; and Jan Peterson, James Russell, Steve Flinn, and Fern Bennett, valued IU professional staff (as well as friends and colleagues) who have provided indispensable infrastructural and logistical support to our operations.

Most of all, I would like to thank my amazing staff, without whom I could not possibly do what I do. James Moskowitz is an exceptional Managing Editor. He combines business experience, strong communication and computer skills, a real aesthetic sensibility, and the scholarly perspective of an advanced and published political science Ph.D. student. James has contributed immeasurably to the success of the journal along every dimension, from the efficient operation of the EM system to the journal's terrific new design, and he is responsible for the extraordinary covers we have featured in the past three years. James works full-time on the journal. In August of 2010 Margot Morgan became the full-time Book Review Managing Editor, when she received her Ph.D. from Rutgers University. Margot has worked with me (along with James) on the journal since I first became Book Review Editor seven years ago, and she is the point person regarding copyediting and production of the Review section. Over the past seven years James and Margot have been joined by a core of equally terrific Editorial Associates whose contributions far exceed the 20 hours of work per week that their assistantships entail. I would like to thank them all, alphabetically: Shanna Dietz, Beth Easter, Adrian Florea, Peter S. Giordano, Emily Hilty, Carolyn Holmes, Rafael Khachaturian, Luke Mergner, Hicham Bou Nassif, Katie Scofield, Rebekah Tromble, Brendan Westler, and Rafia Zakaria. It is my great pleasure to thank these people by name, because of the work they have done, but also because the huge contributions of graduate students to the work of our professional journals too often go unrecognized.

In its ten years of operation Perspectives has published over 250 articles and essays, and over 3000 book reviews, and it has benefited from the anonymous contributions of many thousands of manuscript reviewers. Perspectives is truly a collaborative endeavor and public product for which our entire discipline should feel a sense of accomplishment and pride.

\section{"Post-Katrina New Orleans": What's in This Special Issue and Why it Matters}

In recent years we have tried to combine article placement and special Book Review features and topical sections to highlight certain important themes — gender and politics, violence and politics, democratization, etc.- that political science does and should address. By highlighting political themes rather than merely reproducing conventional disciplinary markers and subfield labels, we seek deliberately to foster broader scholarly communication in political science. The theme of this issue- "Post-Katrina New Orleans"-is a bit different, because it symbolically references a very specific place and time and also condenses a wide range of more general political themes, including urban politics, power, vulnerability, "disaster" and postdisaster recovery, racialized and gendered inequality, and the limits of political representation.

While Hurricane Katrina raged across the Gulf of Mexico in the final days of August 2005, over seven thousand political scientists were attending the APSA Annual Meeting in Washington, D.C. We watched in horror as the hurricane leveled entire communities and took almost two thousand lives. And in the days and weeks that followed, we watched this natural disaster unfold as a cataclysmic human, social, and political disaster, vividly symbolized by the wholesale flooding and destruction of a major US city and the displacement of its entire population of over 450,000 people, and by the paralysis of major national institutions in the face of this disaster. In the wake of this event major questions were posed about emergency preparedness, disaster relief, post-disaster reconstruction, and what seemed to be the utter failure of political institutions at all levels to anticipate and to respond to this cataclysm. At the same time, at a level both more elemental and more profound, the disaster manifested extraordinary human vulnerability, suffering, and powerlessness, in a fashion that begged for the kind of understanding that the social sciences at their best can provide.

As our staff began planning this special anniversary issue, it seemed particularly appropriate for the issue to be framed around the politics of post-Katrina New Orleans and, even more broadly, around the symbolic meanings of "post-Katrina New Orleans." For the term denotes not simply a very specific time and place, but also a set of core themes: urban neglect and reconstruction; the vulnerability and resilience of civil society; the responsiveness and non-responsiveness of liberal democratic political institutions; the ways that the devolution and privatization of political intitutions generates predation and corruption; and the intersections of race, class, gender, sexuality, and other forms of marginality. This latter point seems especially important to note given the controversies within APSA (including the organization of a boycott) regarding the siting of the annual meeting in New Orleans despite Louisiana’s "Super DOMA" constitutional provision proscribing the legal recognition of same-sex couples, which many experts regard as the most severe version of such a provision to have been passed in the US. For much of the discussion of these issues within 
the profession has centered on the tension between two very different narratives of New Orleans-the city as the site of cataclysmic disaster, especially for residents who were poor and/or people of color vs. the state of Louisiana (and thus the city) as a site of homophobia and suppression of difference.

It is obviously beyond the scope of this special issue or the legitimate purpose of this journal to fully address, much less resolve, the analytical and political issues at stake. But it is just as obviously a great virtue of a journal such as this one that it can feature excellent work that highlights the many perspectives that political science can bring to bear on such issues. We are thus pleased to include a wide range of pieces dealing directly with post-Katrina New Orleans and with the broader issues it presents.

Kevin Fox Gotham's "Disaster, Inc.: Privatization and Post-Katrina Rebuilding in New Orleans" is a research article focused on the reorganization of the Federal Emergency Management Agency (FEMA) as a service purchaser and arranger in the wake of the Homeland Security Act of 2002, and on the way the broader devolution and privatization of public services fatally weakened both emergency planning for and emergency responses to the Katrina disaster. As Gotham states in his conclusion: "This paper draws on social science scholarship on networked governance and neoliberalization to identify and explain the negative consequences of the private sector implementation of emergency management policy in the aftermath of the Hurricane Katrina disaster. Privatization in the realm of emergency management policy and disaster recovery services raises several issues fundamental to notions of civil society, community, and citizenship. By providing assistance to communities affected by disasters, the state aids its citizens, asserts its power, and reproduces its sovereignty. In shifting emergency management responsibilities from government to market, privatization addresses disaster victims not as citizens and members of an aggrieved community but as atomized customers, clients, and consumers. In doing so, privatization obscures liability and accountability for problematic post-disaster outcomes, and disarticulates public purposes vis-à-vis post-disaster recovery and rebuilding activities. Moreover, the consequences of privatization are hardly the same for all groups affected by disasters. Some groups and organized interests will benefit and others will suffer when the implementation of emergency management policy is shifted to private actors."

Gotham's analysis of bureaucratic politics is nicely complemented by our symposium on Cedric Johnson's The Neoliberal Deluge: Hurricane Katrina, Late Capitalism, and the Remaking of New Orleans, an important anthology on the dynamics of "remaking New Orleans" and the limits of that effort. The book, which includes contributions from across the social sciences, centers on the themes of privatization, marketization, and neoliberalism that are also crucial to Gotham's account. And our symposium includes a range of commentaries on these themes by Christopher J. Coyne, Margaret E. Farrar, Martin F. Manalansan IV, Matt Sakakeeny, Aaron Schneider, Jessica L. Trounstine, and Thad Williamson. (Martin's reflection on the intersections of race, ethnicity, and sexuality in New Orleans is particularly germane given the controversies about the APSA conference siting. As he writes: "It is crucial, then, to take seriously the issue of sexuality and queerness/non-normativity not as an empty gesture toward a mythic history but as a consideration of the ways in which alternative solutions can be constructed through the lives of people who have always been seen as marginal to the mainstream").

William Paul Simmons and Monica J. Casper's essay, "Culpability, Social Triage, and Structural Violence in the Aftermath of Katrina," also deals with the failures and injustices marked by Katrina, though with a greater focus on questions of marginality and vulnerability than on political economy and public policy. Simmons and Casper deploy a range of critical perspectives, from Steven Lukes' Power: A Radical View and some of its critics, to "postmodern" concerns with "ocularity" and the connections between the "visibility" and "invisibility" of social problems and marginal groups, to theories of "structural violence." Their central concept is social triage, which references practices of emergency response and social reconstruction that focus on rescuing those most "saveable" at the cost of those most vulnerable, and that allow "broader issues of environmental justice, poverty, and racism endemic to Louisiana and the Gulf region [to] be set aside." According to Simmons and Casper, post-Katrina New Orleans is best summed up in the title of the 2008 protest album by native son musician and celebrity Dr. John-City That Care Forgot: "The New Orleans referenced in the songs, poetry, and literature that emerged from Katrina is a different city, one forsaken by government and tourists alike, and one whose most vulnerable citizens are removed to the cultural landfill like so much hazardous waste." Simmons and Casper note that: "There was, in fact, a deluge of visual images associated with Hurricane Katrina .... The hurricane's visual legacy could be found in pictures of the bodies abandoned in nursing homes and hospitals, the families huddled on near-submerged rooftops, the dead pets entangled in sodden foliage and debris, and of course nightmarish scenes at the Louisiana Superdome and the Ernest N. Morial Convention Center ... [yet] despite the visual proliferation of horror and loss, the structural violence and its victims almost immediately became invisible once again, crusted over with the noxious grime of racism, graft, and historic federal dismantling of urban infrastructures through defunding."

James Johnson's essay "Aggregates Unseen: Imagining Post-Katrina New Orleans" takes up precisely the question of visibility and its means. Johnson is interested in photography as a medium of experience and of what 
Hannah Arendt called an "enlarged mentality," allowing citizens to appreciate experiences and perspectives other than their own. Johnson poses a profound question: How can photography depict a disaster of Katrina's geographic scope? As he notes: "Katrina drove over a million and a half people from their homes in the coastal region of Louisiana, Mississippi and Alabama in late August 2005 . . . . How might we envision well over a million persons scattered across every, or nearly every, part of the country? The options, at least photographically, are limited." Johnson begins by discussing the limits of the "broadly liberal" tradition of documentary photography most famously associated with Dorothea Lange's 1936 portrait "Migrant Mother," and proceeds to defend the appropriateness of a more jarring and provocative aesthetic, exemplified in the work of photographers Robert Polidori and Richard Misrach. According to Johnson, that work "amplifies our ability to imagine both the disorienting situation confronting New Orleans after Katrina and the ways that people approached that situation. That work 'makes the others present,' in Arendt's phrase, not by depicting suffering individuals themselves but by depicting the nearly unfathomable destruction from which they fled and the seemingly incalculable tasks they confronted once the danger had passed."

Johnson writes as a political theorist of pragmatist persuasion, interested in visual representation as a political medium that is amenable to interpretive analysis and cultural critique. Simon Stow writes in a similar vein in his essay, "From Upper Canal to Lower Manhattan: Memorialization and the Politics of Loss," a piece on the politics of memory which centers on a comparison of the National September $11^{\text {th }}$ Memorial in Lower Manhattan and the New Orleans Katrina Memorial located at the upper end of Canal Street. Stow analyzes the memorials themselves as public displays, along with the discourse surrounding the planning and reception of these memorials, and through this analysis he identifies what he calls "a bifurcated strategy of memory and mourning embraced by much of the American public; one in which memories of injustices done to the nation are prioritized over injustices perpetuated within it." Stow critiques this bifurcation, and argues that as a local creation, the Katrina Memorial in New Orleans has far more democratically-productive potential than its counterpart in New York City.

Charles B. Hersch also writes in a broad cultural vein in his essay, "Jazz and the Boundaries of Race." (A review of three books written by musicologists and music critics, Hersch's piece is this issue's contribution to our journal's new "Undisciplined" feature). Hersch's essay focuses on a theme central to much commentary on jazz, including the three books under review-the relationship between jazz and race. It offers a nuanced discussion of music in general, and jazz in particular, as a distinctive form of creative expression not reducible to cultural and social practice, but also not immu- nized from the broader cultural, economic, and racial structures of society. The unique history of jazz in New Orleans, the Creole city of its birth, exemplifies these complexities. Hersch points out that while jazz is the "hybrid" American art form par excellence, the American history of race and racism inflects every aspect of this music. And, while jazz epitomizes the creative possibilities of racial "boundary crossings," it is also important to remember "that such crossings always take place in the context of systems of constraint."

Michael C. Dawson's essay "Racial Tragedies, Political Hope, and the Tasks of American Political Science" centers on these racial constraints, which continue to define American politics. Dawson takes his bearings from three episodes-The Trayvon Martin tragedy, the optimistic spectacle of the election and inauguration of Barack Obama during late 2008 and early 2009, and the aftermath of Hurricane Katrina-whose apparent differences conceal a singular truth: "the massive racial cleavages within the U.S.," which account for and also are reproduced by "diametrically opposed world views among blacks and whites." Dawson rejects the notion of a "post-racial" America and, drawing on recent scholarship on both public opinion and "the evolving racial order," he outlines a new agenda of research in US politics that is analytically attentive to the sources of racial difference and division and to the theoretical and practical challenges these differences and divisions pose to American democratic citizenship. Our book symposium on Cathy J. Cohen's Democracy Remixed: Black Youth and the Future of American Politics is a perfect complement to Dawson's argument. In the book Cohen applies her work as founder and principal researcher of the Black Youth Project, drawing also upon a new national survey of black youth, to offer a mixed-method empirical description and theoretical analysis of "black youth and the future of American politics." In the symposium, Yvette Alex-Assensoh, Heath Fogg Davis, Carmen Sirianni, Peter Levine, Taeku Lee, and Mark R. Warren assess the book as a piece of theoretical and applied research and comment more broadly on the importance of black youth to the future of American politics.

Dawson and Cohen in different ways underscore the enduring theoretical and practical importance of America's historical black-white racial divide. Jennifer Hochschild's essay does not deny the importance of this divide in certain ways, at certain moments, and in certain places. But it does raise another set of questions that are well summed up in its title: "Race and Cities: New Circumstances Imply New Ideas." Hochschild's piece centers on a number of dramatic demographic transformations of the US- the growing population of non-black ethnic minorities, especially Latinos; the concentration of these groups in certain cities and regions; the aging of the white population relative to the population of color; and the growing suburbanization of American life, accompanied by the development 
of new urban-suburban linkages. "Our discipline," she writes, "has not yet taken full account of the sea change in the United States' cities and suburbs. In this essay, I highlight some incontrovertible population dynamics and identify controversies about them that are, or should be, occupying the attention of both activists and scholars." Hochschild thus outlines some broad and consequential changes in the US urban and racial profile, and concludes by reflecting programmatically on their likely ramifications for protest politics, electoral politics, and coalition politics more generally.

While Hochschild writes in a descriptive-empirical mode, her analysis is explicit about the implications of the changes she outlines for core democratic values. Clarissa Rile Hayward and Todd Swanstrom's edited volume, Justice and the American Metropolis, more deliberately assembles a distinguished group of social scientists whose work robustly integrates normative and empirical concerns. The book's back cover concisely lays out a central challenge of contemporary politics: "Today's American cities and suburbs are the sites of 'thick injustice'unjust power relations that are deeply and densely concentrated as well as opaque and seemingly intractable. Thick injustice is hard to see, to assign responsibility for, and to change." Our symposium on the book centers around two big questions: (1) how do American cities look when assessed in terms of their "justice" (or "injustice"), and how might they look if they were assessed in these terms more seriously? and (2) how does American political science look when assessed in terms of the extent to which it takes the question of urban justice and injustice seriously? Our symposium features a diverse range of commentaries by Mark Blitz, David Imbroscio, Jody Miller, Paul A. Passavant, Dianne Pinderhughes, and Kent E. Portney.

I hope that the narrative flow of this introduction underscores that an analysis of post-Katrina New Orleans implicates broad questions at the heart of political science. It is with this thought in mind that I turn, finally, to the three articles that appear at the top of this issue's Table of Contents. With the exception of the Kevin Gotham article, everything discussed above was solicited with this special issue in mind. All of our research articles, on the other hand, arrive, blinded, through electronic submission, and the ones that are published are those that make it through our double-blind external review and revision process. The three articles at the top of our Contents were each submitted, reviewed, and accepted for publication, independently, in this way. But we chose to publish them together in this issue because each is a highly theoretical piece that nicely fits with the broad themes raised by this issue: how political institutions structure priorities, privilege some interests at the expense of others, and through their operations generate public goods and bads, public functions and dysfunctions.
Our lead article is a major theoretical contribution to the study of political parties, in the US and more generally. I am thrilled to be publishing it because it is excellent, but also because it employs mixed methods, and utilizes basic formal modeling techniques in an accessible, integrative, and purposeful way. Co-authored by a group of important party scholars, Kathleen Bawn et al.'s "A Theory of Political Parties: Groups, Policy Demands and Nominations in American Politics" presents nothing less than a new, "supply-side" theory of political parties. As the authors state clearly: "We propose a theory of political parties in which interest groups and activists are the key actors. Coalitions of groups develop common agendas and screen candidates for party nominations on loyalty to their agendas. This theoretical stance contrasts with currently dominant theories, which view parties as controlled by election-minded politicians. The difference is normatively important because parties dominated by interest groups and activists are less responsive to voter preferences, even to the point of taking advantage of lapses in voter attention to politics." The theory is logical, parsimonious, grounded in a substantial amount of empirical research in voting behavior and political psychology, and helps make sense of many aspects of partisan competition and the limits of this competition. Its central concept is the idea of an "electoral blind spot," a zone of general voter disengagement and indifference that policy demanders and their partisan agents seek to exploit for their own interests (our Critical Dialogue between Ben Berger and Justin Buchler addresses a very similar theme). As Bawn et al. write, "Bargaining among policy demanders constructs not only the party system, but also the ideological space. The resulting coalitions encompass diverse concerns, some narrowly material and some broadly idealistic. Inevitably, the party programs are less than perfect matches for the concerns of most voters, who respond with varying degrees of trust, adaptation, and confusion." Expanding on themes developed by journalists such as E.J. Dionne, Jr. and political scientists such as Morris Fiorina, they hold that "As with parties, our theory implies that ideology and public discourse in general will be dominated by voices that many voters consider too extreme ... [and] that ideological polarization of elites is not widely shared by ordinary voters." While their theory is intended as a general one, they elaborate on its affinities with recent discussions, in this journal and elsewhere, of whether the current US party system is a form of "organized combat" privileging wealthy and well-organized interests-though it is surely consistent with their theory for other kinds of interests to organize this way as well. (Indeed, one way of reading Terry Moe's book Special Interest, discussed in our March issue, is as an argument about the ways that teachers' unions have developed a strong organizational foothold in the US Democratic party). 
This argument recalls earlier, foundational arguments in US political science by E. E. Schattschneider on organization as the "mobilization of bias" and by Peter Bachrach and Morton Baratz on the importance of "non-decisions." For these reasons, among others, our second research article, Lisa Disch's "Democratic Representation and the Constituency Paradox," is a perfect complement, since it develops a very similar point, in part by drawing more explicitly on this "older" political science. Disch's article is an exemplary work of political theory. It centers on an interpretation of Hanna Pitkin's The Concept of Representation - widely cited by empirical scholars of democracy-based on a critical re-reading of Pitkin's classic study of the philosopher Ludwig Wittgenstein, Wittgenstein and Justice. The piece offers a novel interpretation of Pitkin, according to which "Pitkin's core insight into democratic representation is that democratic representation is 'quasi-performative': an activity that mobilizes constituencies by the interests it claims in their name." But it does much more than this. For Disch situates Pitkin amidst broader 1960's discussions and debates within US political science about the limits of representative democracy (John Schaar and Sheldon Wolin), the biases of pluralism (Bachrach and Baratz, William E. Connolly, etc.), and the concept of power, and then links these discussions to contemporary discussions about the class biases of US politics. As she argues, Pitkin's "constituency paradox": ". . . redirects attention from the typical focus on responsiveness - which tracks congruence between public policy and changes in public opinion and constituent preference- to a system-wide measure that I will term representation's 'constituent effects.' As such, it bears on the contemporary debate regarding democratic 'oligarchy' in the US, and on what Jacob S. Hacker and Paul Pierson have called 'winner-take-all politics.' Through the lens of Pitkin's work, this current work on the political effects of economic inequality is important not for calling attention to the 'differential responsiveness' of the US political system, but for making its constituent effects a focal point of political analysis. That is, it frames a crisis that has more to do with structural powerthe 'bias' of the contemporary democratic system - than with measurable, quantifiable differences in influence of its competing interest groups." This concern with the connections between power and representation is echoed in this issue's Critical Dialogues between Laurel Weldon and Hahrie C. Han on social movements and social policy, and Daniel Carpenter and John Ferejohn on constitutionalism, regulatory regimes, and the politics of capture. It is also addressed by the symposium organized by Associate Editor Henry Farrell on Tim Groseclose's Left Turn: How Liberal Media Bias Distorts the American Mind, which features commentaries by Justin H. Gross, Cosma Rohilla Shalizi and Andrew Gelman, Kathleen Hall Jamieson, Nolan McCarty, Brendan Nyhan, and Nancy Rosen- blum. Each of these discussions raises important questions about whether and how "bias" is mobilized by political institutions and whether and how such biases should or might be contested.

Our issue's third research article, Anna Persson and Martin Sjöstedt's "Responsive and Responsible Leaders: A Matter of Political Will?" is a contribution to theorizing about the political economy of development. Centering on development challenges associated with what Paul Collier has called "The Bottom Billion," and focused mainly on the politics of sub-Saharan Africa, the piece offers a critique of discourses of development that moralize about "enlightened" leaders such as Singapore's former Prime Minister Lee Kuan Yew and the government-led Independent Commission Against Corruption in Hong Kong. Synthesizing state theory and principal-agent theory, Persson and Sjöstedt outline the rudiments of "a more robust theory of leadership behavior ... [providing] theoretically anchored tools for labeling what is now commonly brushed aside and in an ad-hoc manner referred to as "kleptocratic liars, lacking the political will to conduct reform.'” They argue that in most of the world's poorest and least developed regions, "the state is conceived merely as a potential resource to be appropriated, or an instrument to be used in the domination of other groups." And they conclude, following recent work by Robert Bates, and by Douglass C. North, John Joseph Wallis, and Barry R. Weingast, that "ultimately, the construction of a shared social contract demands exchanging a negative equilibrium, in which the state is generally perceived as a resource to be appropriated and politics as a zero-sum game which no one can afford to lose, for a positive equilibrium, in which the state is generally expected to be an instrument of collective action and public goods provision." Their argument is usefully read alongside this issue's Critical Dialogue between Erik Martinez Kuhonta, author of The Institutional Imperative: The Politics of Equitable Development in Southeast Asia, and Emmanuel Teitelbaum, author of Mobilizing Restraint: Democracy and Industrial Conflict in PostReform South Asia. Teitelbaum and Kuhonta disagree productively about the extent to which democratic institutions are a necessary condition of sustained economic development. But they both agree with Persson and Sjöstedt that sustained development is largely a function of institutions.

These discussions seem to move us far from the Gulf Coast of Louisiana. But only in a way. For there are striking parallels between many of the discussions of postKatrina New Orleans and the discussions in the development literature of "kleptocracy," corruption, predation, and "rent-seeking." It may well be that the lack of a durable and legitimate "social contract" in many parts of sub-Saharan Africa has its counterpart in other parts of the "developed" world, of which New Orleans is simply one particularly visible and disturbing example. 
This issue's Book Review section on "Post-Katrina New Orleans" features a wide range of books from across a variety of subfields and perspectives in political science. Readers will note that we have decided to depart from our normal Book Review layout - to which we will return in our next issue-for this special issue, by dispensing with our standard four field categories, and publishing only reviews of books related to our special theme. For the sake of clarity, we have organized these book reviews into four sub-themes that seem particularly germane to our special issue-minority politics, urban politics, disaster and recovery, and private power versus public power. Some of these book reviews focus on the concrete problems of New Orleans and other cities dealing with crisis. Some of them focus on broader problems of political representation and public goods provision. What they share in common is a concern with the institutional sources of vulnerability and deprivation made visible by social crises and disasters, and with the challenges these pose to questions of human dignity, democratic citizenship, and sometimes of bare human survival.

Political science at its best can illuminate these questions in ways that make them amenable to intelligent public discussion and constructive public action. Perspectives on Politics aspires to function as an open and engaging medium of scholarly publicity and communication in political science, a robust public sphere that complements the other forms of publicity characteristic of our discipline and that feeds into the broader streams of publicity that constitute the academy as a global republic of letters and the world as a potential space of humane public responsibility.

The theme of "post-Katrina New Orleans," whether taken literally or figuratively, can well seem demoralizing. At the same time, it can also be viewed as a catalyst for serious and creative thinking. It is our hope with this issue to highlight the significant contributions-and untapped possibilities that lie beyond them - of which our discipline is capable. It is fitting, perhaps, to close with a brief comment on the image that adorns this issue's cover, a photograph by Richard Misrach discussed in James Johnson's essay. Johnson notes that "Misrach depicts an opening. The question is what can be made of it. After all, no one provided returning evacuees with magical ruby slippers. The back cover of Destroy this Memory depicts a boarded window on which someone has posed that question acutely- 'WHAT NOW?'” What now? indeed. We hope that this special issue of Perspectives on Politics will not simply mark the tenth anniversary of the journal, but will honor, and stimulate, the impulse that has fueled the journal from the beginningthe impulse to promote forms of political science research and writing that are at once scholarly, serious, engaging, and mindful of their place in a world clearly in need of greater understanding. 


\section{Statement of Mission and Procedures}

Perspectives on Politics seeks to provide a space for broad and synthetic discussion within the political science profession and between the profession and the broader scholarly and reading publics. Such discussion necessarily draws on and contributes to the scholarship published in the more specialized journals that dominate our discipline. At the same time, Perspectives seeks to promote a complementary form of broad public discussion and synergistic understanding within the profession that is essential to advancing scholarship and promoting academic community.

Perspectives seeks to nurture a political science public sphere, publicizing important scholarly topics, ideas, and innovations, linking scholarly authors and readers, and promoting broad reflexive discussion among political scientists about the work that we do and why this work matters.

Perspectives publishes work in a number of formats that mirror the ways that political scientists actually write:

Research articles: As a top-tier journal of political science, Perspectives accepts scholarly research article submissions and publishes the very best submissions that make it through our double-blind system of peer review and revision. The only thing that differentiates Perspectives research articles from other peer-reviewed articles at top journals is that we focus our attention only on work that in some way bridges subfield and methodological divides, and tries to address a broad readership of political scientists about matters of consequence. This typically means that the excellent articles we publish have been extensively revised in sustained dialogue with the editor-me- to address not simply questions of scholarship but questions of intellectual breadth and readability.

"Reflections" are more reflexive, provocative, or programmatic essays that address important political science questions in interesting ways but are not necessarily as systematic and focused as research articles. These essays often originate as research article submissions, though sometimes they derive from proposals developed in consultation with the editor in chief. Unlike research articles, these essays are not evaluated according to a strict, doubleblind peer review process. But they are typically vetted informally with editorial board members or other colleagues, and they are always subjected to critical assessment and careful line-editing by the editor and editorial staff.

Scholarly symposia, critical book dialogues, book review essays, and conventional book reviews are developed and commissioned by the editor in chief, based on authorial queries and ideas, editorial board suggestions, and staff conversations.

Everything published in Perspectives is carefully vetted and edited. Given our distinctive mission, we work hard to use our range of formats to organize interesting conversations about important issues and events, and to call attention to certain broad themes beyond our profession's normal subfield categories.

For further details on writing formats and submission guidelines, see our website at http://www.apsanet.org/ perspectives/ 